\title{
Coexistence of the Hypersecretion of Catecholamine, Adrenal Cortical Nodular Hyperplasia, and Nephrotic-Range Proteinuria of Focal Segmental Scleronephrosis: Is It Fat-Induced Hypertension?
}

\author{
Khanh vinh quốc Lương ${ }^{1}$, Lan Thị Hòang Nguyễn ${ }^{1}$, Sĩ văn Nguyễn ${ }^{2}$, Ninh T. Nguyễn ${ }^{3}$ \\ ${ }^{1}$ Vietnamese American Research Foundation, Westminster, USA; ${ }^{2}$ Department of Pathology/Garden Grove Medical Center, Garden \\ Grove, USA; ${ }^{3}$ Department of Surgery/UCI Medical Center, Orange, USA. \\ Email: Lng2687765@aol.com
}

Received January $1^{\text {st }}, 2011$; revised March $15^{\text {th }}, 2011$; accepted April $6^{\text {th }}, 2011$.

\begin{abstract}
Two patients had a long history of hypertension and one of them also had a nephrotic-range proteinuria secondary to focal segmental scleronephrosis which had been diagnosed by kidney biopsy. They presented with uncontrolled hypertension. Laboratory examination suggested hypersecretion of catecholamines by the left adrenal glands in both patients and primary aldosteronism in one of them. A computed tomography scan revealed small nodules on left adrenal gland in both patients. Patients underwent laparoscopic left adrenalectomy. After surgery, blood pressure was normalized and proteinuria was resolved. Most interestingly, prominent adipocytes infiltrated were detected in the adrenal cortex and were associated with the presence of lymphocytes, which suggested that adipocytes might have a role in the pathogenesis of these diseases in our patients.
\end{abstract}

Keywords: Pheochromocytoma, Aldosteronism, Adipocyte, Nephrotic Syndrome, Focal Segmental Scleronephrosis, Adrenal Cortical Hyperplasia

\section{Introduction}

Obesity is a known risk factor for both cardiovascular disease and mortality. Adipose tissue is a secretory organ that produces a variety of bio active substances (adipokines) and is involved in the regulation of various biological processes. Adipokines may interact with many organs in the body, such as blood vessels, adrenal glands, and kidneys. In literature, fatty infiltration has been noted in adrenal glands. Park et al. [1] reported a case of Cushing's syndrome with high basal plasma catecholamine levels. They found that lymphocytic infiltration and fatty metaplasia were prominent histological features within the nodules of the cortical adrenal gland. Boyanton et al. [2] also presented a man with an adrenal tumor and high catecholamine levels but the histopathologic examination revealed mature adipocytes and focal hematopoietic elements with normal com- pressed adrenal tissue. Finally, Ajmi et al. [3] reported another patient with an adrenal mass and elevated cortisol and androgen levels; however, mixed components of fat and adrenal tissue were only seen on the pathological specimen.

In the present cases, we will discuss the possible role of adipocytes that may involve in the pathogenesis in our patients with hypersecretion of catecholamines, adrenal cortical nodular hyperplasia, and nephrotic-range proteinuria secondary to focal segmental sclerosis of the kidneys.

\section{Case Presentation}

Patient A: A 56-year-old Vietnamese man with a 10year history of hypertension was being treated with amlodipine $10 \mathrm{mg}$ twice a day and amidarone $200 \mathrm{mg}$ daily. His weight and height were $159 \mathrm{lbs}$. and 5 feet, respectively. He complained of more frequently palpitation, 
anxiety, fatigue, and his blood pressure (BP) had been uncontrolled at home. Laboratory examination showed a serum potassium of $4.3 \mathrm{mmol} / \mathrm{L}$ (normal, 3.6 - 5.0), serum sodium of $141 \mathrm{mmol} / \mathrm{L}$ (normal, 135 - 145), serum chloride of $108 \mathrm{mmol} / \mathrm{L}$ (normal, 96 - 109), serum total carbon dioxide of $26.6 \mathrm{mmol} / \mathrm{L}$ (normal, 20 - 30), serum creatinine of $1.5 \mathrm{mg} / \mathrm{dl}$ (normal, $0.7-1.3$ ), serum blood urea nitrogen (BUN) of $23 \mathrm{mg} / \mathrm{dl}$ (normal, 5 - 26), serum glucose of $87 \mathrm{mg} / \mathrm{dl}$ (normal, 65 - 99), and serum thyroid stimulating hormone (TSH) of $3.34 \mathrm{uIU} / \mathrm{ml}$ (normal, 0.5 1.5). Further blood tests revealed plasma renin of 4.9 $\mathrm{ng} / \mathrm{ml} / \mathrm{hr}$ (normal, 1.3 - 4), serum aldosterone of $3.5 \mathrm{ng} / \mathrm{dl}$ (normal, 1 - 15), serum cortisol $11.1 \mu \mathrm{g}$ (normal, 3.1. 22.4), 24-hours urine for metanephrine of $213 \mu \mathrm{g}$ (normal, 35 - 350), 24-hours urine for vanillylmandelic acid (VMA) of $6.2 \mathrm{mg}$ (normal, 0 - 6), plasma free normetanephrine of $1.19 \mathrm{nmol} / \mathrm{L}$ (normal, <0.9), plasma norepinephrine of $580 \mathrm{pg} / \mathrm{ml}$ (normal, <399), plasma epinephrine of $206 \mathrm{pg} / \mathrm{ml}$ (normal, <99), serum chromogranin A of 51/ml (normal, 0 - 50). A computed tomography (CT) scan of the adrenal gland showed a nodule $0.9 \mathrm{~cm}$ at the left adrenal limb.

He then underwent laparoscopic left adrenalectomy. The specimen consisted of two pieces of adrenal gland measuring $6 \times 4.5 \times 0.7 \mathrm{~cm}$ in aggregate. The adrenal is covered with multilobular adipose tissue. Pathological examination reported a cortical nodular hyperplasia of the adrenal gland (Figure 1(a)). Most interestingly, there were abundant adipocytes in the adrenal cortex in association with the presence of lymphocytic infiltration (Figures 2(a) and 3(a)).

After surgery, his BP has been stable (110/70), and subsequent levels of serum catecholamine and urinary VMA decreased to normal values.

Patient B: A 56-year-old Vietnamese man with a 20-year history of hypertension was being treated with valsartan $320 \mathrm{mg}$, amlodipine $10 \mathrm{mg}$, and benazepril 20 $\mathrm{mg}$ daily. His weight and height were $161 \mathrm{lbs}$. and 5 feet $1 / 4$ inches, respectively. He complained of cramping in his extremities and his BP had been uncontrolled at home. Laboratory examination showed a serum potassium of $3.1 \mathrm{mmol} / \mathrm{L}$ (normal, 3.6 - 5.0), serum sodium of 139 $\mathrm{mmol} / \mathrm{L}$ (normal, 135 - 145), serum chloride of 99 $\mathrm{mmol} / \mathrm{L}$ (normal, 96 - 109), serum total carbon dioxide of $25 \mathrm{mmol} / \mathrm{L}$ (normal, 20 - 30), serum creatinine of 1.5 $\mathrm{mg} / \mathrm{dl}$ (normal, 0.7 - 1.3), serum blood urea nitrogen (BUN) of $25 \mathrm{mg} / \mathrm{dl}$ (normal, 5 - 26), serum glucose of $103 \mathrm{mg} / \mathrm{dl}$ (normal, 65 - 99), serum thyroxine (T4) of 6.8 $\mu \mathrm{g} / \mathrm{dl}$ (normal, 4.5 - 12), serum thyronine uptake of $34 \%$ (normal, 24 - 39), and serum thyroid stimulating hormone (TSH) of $1.6 \mathrm{uIU} / \mathrm{ml}$ (normal, 0.5 - 1.5). Further blood tests revealed plasma renin of $<0.1 \mathrm{ng} / \mathrm{ml} / \mathrm{hr}$

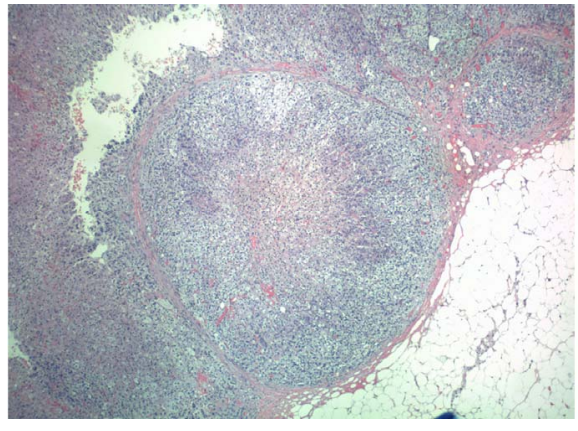

(a)

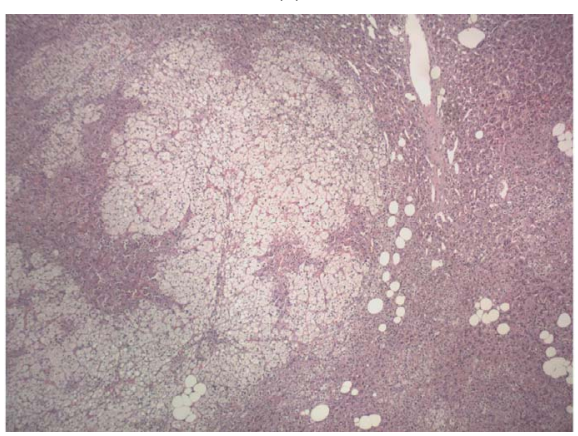

(b)

Figure 1. Photomicrograph $(10 \times)$ showing nodular hyperplasia of the adrenal cortex. The nodule in the left field is composed of mostly large clear cells.

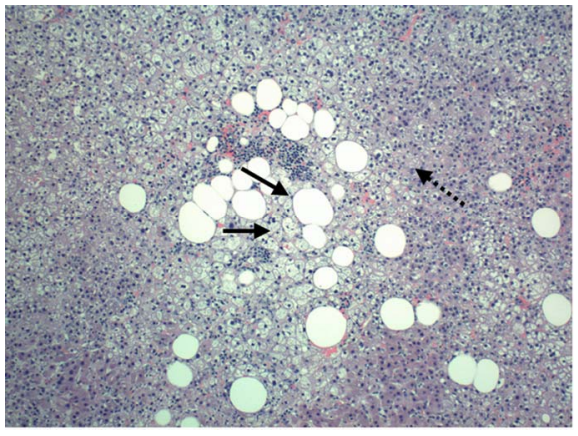

(a)

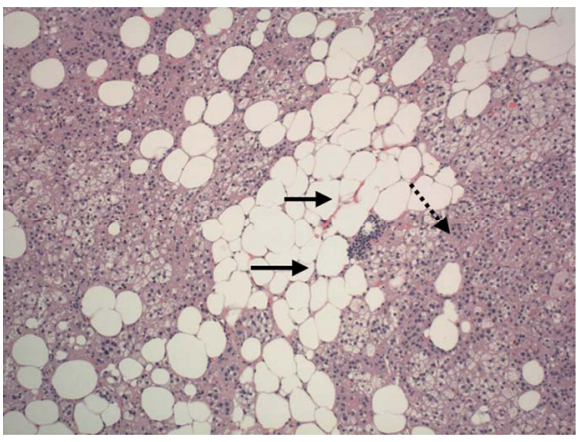

(b)

Figure 2. Photomicrograph $(10 \times)$ showing infiltrates of numerous adipocytes $(\rightarrow)$ and adjacent lymphocytes $(\cdots \rightarrow)$ in the adrenal cortex. 


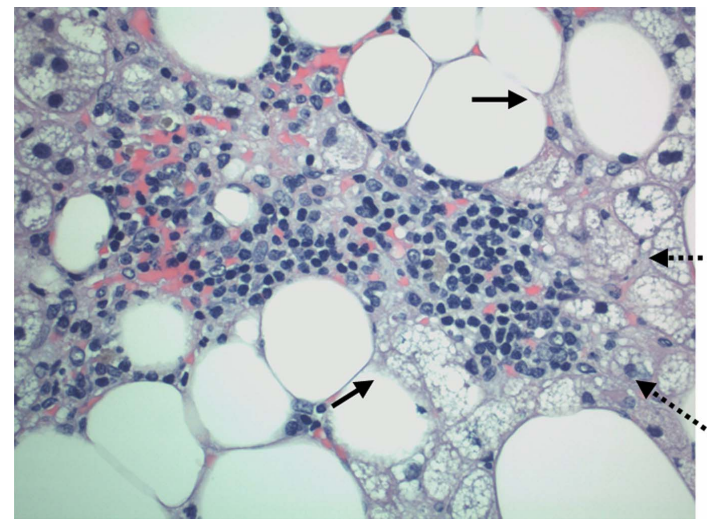

(a)

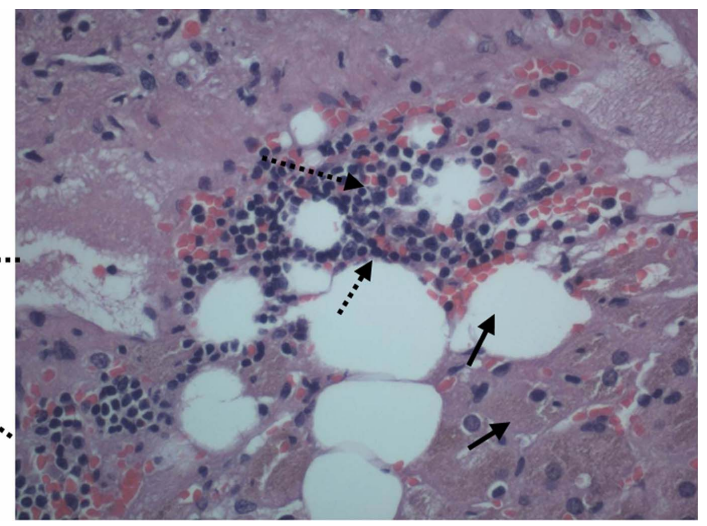

(b)

Figure 3. Photomicrograph $(40 \times)$ showing infiltrates of adipocytes $(\rightarrow)$ and adjacent lymphocytes $(\cdots \rightarrow)$ in the adrenal cortex.

(normal, 1.3 - 4), serum aldosterone of $17.1 \mathrm{ng} / \mathrm{dl}$ (normal, 1 - 15), serum cortisol $11.8 \mu \mathrm{g}$ (normal, 3.1 - 22.4), 24-hours urine for metanephrine of $503 \mu \mathrm{g}$ (normal, 35 350), 24-hours urine for vanillylmandelic acid (VMA) of $17 \mathrm{mg}$ (normal, 0 - 6), plasma free normetanephrine of $0.96 \mathrm{nmol} / \mathrm{L}$ (normal, $<0.9$ ), plasma free metanephrine of $0.35 \mathrm{nmol} / \mathrm{L}$ (normal, $<0.5$ ), serum chromogranin A of 109/ml (normal, 0 - 50). A computed tomography (CT) scan of the adrenal gland showed the left adrenal limb at $1.8 \times 0.9 \mathrm{~cm}$ compared to the right adrenal limb at $1.7 \times$ $0.2 \mathrm{~cm}$. An adrenal vein sample found plasma free metanephrine of $24.9 \mathrm{nmol} / \mathrm{L}$ in the left adrenal vein and $<0.2 \mathrm{nmol} / \mathrm{L}$ in the right adrenal vein. Also, plasma free normetanephrine was $4.95 \mathrm{nmol} / \mathrm{L}$ in the left adrenal vein and $0.44 \mathrm{nmol} / \mathrm{L}$ in the right adrenal vein.

He also has had a history of more than 30 years of proteinuria, ranging from 2000 - $4000 \mathrm{mg} /$ day with mild chronic renal failure and serum creatinine of 1.4 to 1.7 $\mathrm{mg} / \mathrm{dl}$. He had a kidney biopsy, suggestive of focal segmental sclerosis (FSS) of the kidney. Before surgery, his 24-hours urine collection for protein and serum creatinine was $2851.6 \mathrm{mg}$ and $1.9 \mathrm{mg} / \mathrm{dl}$, respectively.

He was started on spironolactone $25 \mathrm{mg}$ twice a day orally with good blood pressure controlled (120/70). His serum potassium was $5.2 \mathrm{mmol} / \mathrm{dl}$. Also, valsartan, amlodipine, and benazepril were discontinued.

He then underwent laparoscopic left adrenalectomy. The specimen consisted of fibroadipose tissue measuring $11.5 \times 3 \times 3 \mathrm{~cm}$ with the left adrenal gland measuring $7 \times$ $1 \times 1 \mathrm{~cm}$. The entire specimen weighed $42 \mathrm{~g}$. Pathological examination reported a section in a longitudinal orientation but none in transverse section. Unfortunately, the specimen did not show the medullary portion of the adrenal gland. However, pheochromocytoma could not be entirely excluded based on the available sections. Still, changes in the adrenal cortex were suggestive of nodular hyperplasia (Figure 1(b)). Most interestingly, there were abundant adipocytes in the adrenal cortex in association with the presence of lymphocytic infiltration (Figures 2(b) and 3(b)).

After surgery, spironolactone was discontinued and his BP has been stable (110/70). The laboratory examination revealed serum creatinine of $1.53 \mathrm{mg} / \mathrm{dl}$, serum glucose of $80 \mathrm{mg} / \mathrm{dl}$, serum BUN of $17 \mathrm{mg} / \mathrm{dl}$, serum sodium of $136 \mathrm{mmol} / \mathrm{L}$, serum chloride of $100 \mathrm{mmol} / \mathrm{L}$, serum total carbon dioxide of $22 \mathrm{mmol} / \mathrm{L}$, and urine protein of 320 $\mathrm{mg} / 24 \mathrm{hrs}$. Subsequent levels of serum catecholamine, renin, aldosterone, and urinary VMA decreased to normal values.

\section{Discussion}

Pheochromocytoma, a catecholamine-secreting tumor, arises from chromaffin cells of the adrenal medulla that is rare. The simultaneous occurrence of adrenomedullary and adrenocortical tumors is extremely rare. There are only five reported cases in the literature [4]. We have suggested that a local interaction between the adrenocortical and medullary areas may involved.

To our knowledge, coexistence of the the hypersecretion of the catecholamine, adrenal cortical nodular hyperplasia, and nephrotic-range proteinuria secondary to focal segmental scleronephrosis (FSS) has not been reported in the literature. Most interestingly, a prominent adipocyte infiltrate in the adrenal cortex was seen in association with the presence of lymphocytes, which suggested that adipocyte might have a role in the pathogenesis of these concomitant diseases in our patients.

Obesity has been associated with increased macrophage infiltration of adipose tissue, and these macrophages may be an important component of the chronic inflammatory response involved in the development of obesity-associated disease. In obese patients, Weisberg et 
al. [5] showed that adipose tissue contains an increased number of macrophages. Drastic weight loss resulted in both a significant decrease in macrophage number and changes in chemoattractant gene expression in adipose tissue [6]. The mechanism of macrophage recruitment to adipose tissue presumably involves increased secretion of chemotactic molecules by adipocytes, such as the C-C motif chemokine ligand 2 (CCL2 or monocyte chemoattractant protein-1) [7-8].

A link between adipose tissue and the cortical adrenal gland, particularly via the mineralocorticoid aldosterone, has already been demonstrated. Gene expression in the renin-angiotensin-aldosterone system (RAAS) was increased in the adipose tissue from obese animal models and human subjects $[9,10]$. There are reports of high levels of circulating angiotensinogen (AGT), rennin and aldosterone; and high levels of activity of angiotensinconverting enzyme (ACE) in obese patients [11,12]. Weight loss is also associated with a decrease in serum aldosterone, plasma renin activity, angiotensinogen and ACE levels [13,14]. Ehrhart-Bornstein et al. [15] incubated fat cells in a conditioned medium from primary mammary gland adipocyte cultures-with NCI-H295R adrenocortical cells for 24 hours. They found that adipocyte secretory products directly stimulate aldosterone secretion 7-fold in human adrenocortical cells (NCIH295R). This effect is independent of adipose angiotensin II. Possible molecular mechanisms involved in this aldosterone secretion include acidity by either an oxidized derivative of linoleic acid [16] or by a potent mineralocorticoid-releasing factor [15] contained in a medium conditioned by human adipocytes. Furthermore, Schinner et al. [17] suggested that the Wnt-signaling pathway is one of the mechanisms mediating the effects of fat cells on adrenal steroidogenic acute regulatory (StAR) transcription as well as cortisol and aldosterone secretion.

The interaction of the sympatho-adrenomedullary system with adipose tissue has been reported in the literature. Resting plasma norepinephrine was found to be a positive predictor of changes in body mass index [18]. Leptin is an adipostatic hormone synthesized and secreted by fat tissues [19]. Plasma leptin concentrations are elevated in obese subjects [20]. Glasow et al. [21] investigated a functional leptin receptor in human adrenal tissue and, they showed a differential action of leptin on human adrenocortical and chromaffin cell hormone production. Leptin directly stimulates catecholamine secretion and synthesis in cultured porcine adrenal medullary chromaffin cells [22].

The association between obesity and nephrotic-range proteinuria was first reported in 1974 [23]. Since then,
FSS has been linked to massive obesity $[24,25]$. Obesity-related FSS is distinctive from idiopathic FSS as it is associated with lower incidence of nephrotic syndrome and has a more indolent course [26]. However, drastic weight reduction is associated with a resolution of this nephrotic syndrome [27]. Plasma adrenomedullin (AM) has been isolated from human pheochromocytomas and adipose tissue $[28,29]$. High levels of plasma AM have been reported in obese subjects [30]. Plasma AM decreased significantly after weight loss from gastric bypass surgery [31]. That plasma AM directly related to the level of proteinuria [32] and changes in AM levels may be the result of heavy proteinuria [33].

In summary, our patients presented with hypersecretion of catecholamine, cortical nodular hyperplasia of the adrenal gland. After surgery, their blood pressures were normalized. Nephrotic-range proteinuria was resolved in one patient. Most interestingly, prominent adipocytes infiltrated were seen in the adrenal cortex in association with the presence of lymphocytes, which suggested that adipocytes might have a role in the pathogenesis of these diseases in our patient. However, a coincidence of these diseases cannot be excluded.

\section{REFERENCES}

[1] Y. K. Park, Y. W. Kim, J. W. Kim, Y. K. Choi, Y. T. Ko, S. W. Ko and M. H. Yang, "Bilateral Primary Pigmented Nodular Adrenocortical Disease-A Case Report Describing a Rare Cause of Cushing's Syndrome," Journal of Korean Medical Sciences, Vol. 9, No. 6, 1994, pp. 450-457.

[2] Jr. B. L. Boyanton, O. Hampel and M. L. Ostrowski, “A 55-Year-Old Man with a Rib Fracture," Archives of Pathology and Laboratory Medicine, Vol. 130, No. 1, 2006, pp. e13-e14.

[3] T. S. Ajmi, C. M. Chaieb, M. Mokni, R. Braham, K. Ach, A. Maaroufi and L. Chaieb, "Corticomedullary Mixed Tumor of the Adrenal Gland," Annales d'Endocrinologie (Paris), Vol. 70, No. 6, 2009, pp. 473-476.

doi:10.1016/j.ando.2009.09.003

[4] K. V. Q. Luong and L. T. H. Nguyen, "Coexistence of Primary Aldosteronism and Pheochromocytoma in a Vietnamese Patient," The Endocrinologist, Vol. 6, No. 6, 1996, pp. 490-493. doi:10.1097/00019616-199611000-00011

[5] S. P. Weisberg, D. McCann, M. Desai, M. Rosebaum, R. L. Leibel and A. W. Ferrante Jr., "Obesity Is Associated with Macrophage Accumulation in Adipose Tissue," The Journal of Clinical Investigation, Vol. 112, No. 12, 2003, pp. 1796-1808. doi:10.1172/JCI19246

[6] R. Cancello, C. Henegar, N. Viguerie, S. Taleb, C. Poitu, C. Rouault, M. Coupaye, V. Pelloux, D. Hugol, J. C. Bouillot, A. Bouloumié, G. Barbatelli, S. Cinti, P. A. Svensson, G. S. Barsh, J. D. Zucker, A. Basdevant, D. 
Langin and K. Clément, "Reduction of Macrophage Infiltration and Chemoattractant Gene Expression Changes in White Adipose Tissue of Morbidly Obese Subjects after Surgery-Induced Weight Loss," Diabetes, Vol. 54, No. 8, 2005, pp. 2277-2286. doi:10.2337/diabetes.54.8.2277

[7] P. Sartipy and D. J. Loskutoff, "Monocyte Chemoattractant Protein 1 in Obesity and Insulin Resistance," Proceedings of the National Academy of Sciences of the United States of America, Vol. 100, No. 12, 2003, pp. 7265-7270. doi:10.1073/pnas.1133870100

[8] J. M. Bruun, A. S. Lihn, S. B. Pedersen and B. Richelsen, "Monocyte Chemoattractant Protein-1 Release is Higher in Visceral than Subcutaneous Human Adipose Tissue (AT): Implication of Macrophages Resident in the AT," The Journal of Clinical Endocrinology and Metabolism, Vol. 90, No. 4, 2005, pp. 2282-2289.

doi: $10.1210 /$ jc. $2004-1696$

[9] F. Massiéra, M. Bloch-Faure, D. Ceiler, K. Murakami, A. Fukamizu, J. M. Gasc, A. Quignard-Boulangé, R. Negrel, G Ailhaud, J. Seydoux, P. Meneton and M. Teboul, "Adipose Angiotensinogen Is Involved in Adipose Tissue Growth and Blood Regulation," The FASEB Journal, Vol. 15, No. 14, 2001, pp. 2727-2729.

[10] G. Giacchetti, E. Faloi, B. Mariniello, C. Sardu, C. Gatti, M. A. Camilloni, M. Guerrieri and F. Mantero, "Overexpression of the Renin-Angiotensin System in Human Visceral Adipose Tissue in Normal and Overweight Subjects," American Journal of Hypertension, Vol. 15, No. 5, 2002, pp. 381-388. doi:10.1016/S0895-7061(02)02257-4

[11] R. Cooper, N. McFarlane-Andersen, F. I. Bennett, R. Wilks, A. Puras, D. Tewksburry, R. Ward and T. Forrester, "ACE, Angiotensinogen and Obesity: A Potential Pathway Leading to Hypertension," Journal of Human Hypertension, Vol. 11, No. 2, 1997, pp. 107-111. doi:10.1038/sj.jhh. 1000391

[12] T. L. Goodfriend, B. M. Egan and D. E. Kelley, "Aldosterone in Obesity," Endocrine Research, Vol. 24, No. 3-4, 1998, pp. 789-796. doi:10.3109/07435809809032689

[13] M. L. Tuck, J. Sowers, L. Dornfeld, G. Kledzik and M. Maxwell, "The Effect of Weight Reduction on Blood Pressure, Plasma Renin Activity, and Plasma Aldosterone Levels in Obese Patients," The New England Journal of Medicine, Vol. 304, No. 16, 1981, pp. 930-933. doi:10.1056/NEJM198104163041602

[14] S. Engeli, J. Böhnke, K. Gorzelniak, J. Janke, P. Schling, M. Bader, F. C. Luft and A. M. Sharma, "Weight Loss and the Renin-Angiotensin-Aldosterone System," Hypertension, Vol. 45, No. 3, 2005, pp. 356-362. doi:10.1161/01.HYP.0000154361.47683.d3

[15] M. Ehrhart-Bornstein, V. Lamounier-Zepter, A. Schraven, J. Langenbach, H. S. Willenberg, A. Barthel, H. Hauner, S. M. McCann, W. A. Scherbaum and S. R. Bornstein, "Human Adipocytes Secrete Mineralocorticoid-Releasing Factors," Proceedings of the National Academy of Sciences of the United States of America, Vol. 100, No. 24, 2003, pp. 14211-14216. doi:10.1073/pnas.2336140100

[16] T. L. Goodfriend, D. L. Ball, B. M. Egan, W. B. Camp- bell and K. Nithipatikom, "Epoxy-Keto Derivative of Linoleic Acid Stimulates Aldosterone Secretion," Hypertension, Vol. 43, No. 2, 2004, pp. 358-363. doi:10.1161/01.HYP.0000113294.06704.64

[17] S. Schinner, H. S. Willenberg, D. Krause, M. Schott, V. Lamounier-Zepter, A. W. Krug, M. Ehrhart-Bornstein, M. Bornstein, S. R. Bornstein and W. A. Scherbaum, "Adipocyte-Derived Products Include the Transcription of the StAR Promoter and Stimulate Aldosterone and Cortisol secretion from Adrenocortical Cells through the Wnt-Signaling Pathway," International Journal of Obesity, Vol. 31, No. 5, 2007, pp. 864-870.

[18] K. Masuo, H. Kawaguchi, H. Mikami, T. Orihara and M. L. Tuck, "Serum Uric Acid and Plasma Norepinephrine Concentrations Predict Subsequent Weight Gain and Blood Pressure Elevation," Hypertension, Vol. 42, No. 4, 2003, pp. 474-480. doi:10.1161/01.HYP.0000091371.53502.D3

[19] R. S. Ahima and J. S. Flier, "Leptin," Annual Reviews of Physiology, Vol. 62, 2000, pp. 413-437. doi:10.1146/annurev.physiol.62.1.413

[20] N. Eikelis, G. Lambert, G. Wiesner, D. Kaye, M. Schlaich, M. Morris, J. Hastings, F. Socratous and M. Esler, "Extra-Adipocyte Leptin Release in Human Obvesity and Its Relation to Symphoadrenal Function," American Journal of Physiology, Endocrinology and Metabolism, Vol. 286, No. 5, 2004, pp. E744-E752. doi:10.1152/ajpendo.00489.2003

[21] A. Glasow, A. Haidan, U. Hilbers, M. Breidert, J. Gillespie, W. A. Scherbaum, G. P. Chrousos, and S. R. Bornstein, "Expression of Ob Receptor in Normal Human Adrenals: Differential Regulation of Adrenocortical and Adrenomedullary Function by Leptin," The Journal of Clinical Endocrinology and Metabolism, Vol. 83, No. 12, 1998, pp. 4459-4466. doi:10.1210/jc.83.12.4459

[22] K. Takekoshi, M. Motooka, K. Isobe, F. Normura, T. Manmoku, K. Ishii and T. Nakai, "Leptin Directly Stimulates Catecholamin Secretion and Synthesis in Cultured Porcine Adrenal Medullary Chromaffin Cells," Biochemical and Biophysical Research Communications, Vol. 261, No. 2, 1999, pp. 426-431. doi:10.1006/bbrc.1999.1025

[23] J. R. Weisinger, R. L. Kempson, L. Eldridge and R. S. Swenson, "The Nephrotic Syndrome: A Complication of Massive Obesity," Annuals of Internal Medicine, Vol. 81, No. 4, 1974, pp. 440-447.

[24] R. A. Warnke and R. Kempson, "The Nephrotic Syndrome in Massive Obesity, A Study by Light, Immunofluorescence and Electron Microscopy," Archives Pathology and Laboratory Medicine, Vol. 102, No. 8, 1978, pp. 431-438.

[25] J. C. Jennette, L. Charles and W. Grubb, "Glomerulomegaly and Focal Segmental Glomerulosclerosis Associated with Obesity and Sleep Apnea Syndrome," American Journal of Kidney Diseases, Vol. 10, No. 6, 1987, pp. 470-472.

[26] N. Kambham, G. S. Markowitz, A. M. Valeri, J. Lin and V. D. D’Agati, "Obesity-Related Glomerulopathy: An Emer- 
ging Epidemic,” Kidney International, Vol. 59, No. 4, 2001, pp. 1498-1509. doi:10.1046/j.1523-1755.2001.0590041498.x

[27] Y. Huan, J. E. Tomaszewski and D. L. Cohen, "Resolution of Nephritic Syndrome after Successful Bariatric Surgery in Patients with Biopsy-Proven FSGS," Clinical Nephrology, Vol. 71, No. 1, 2009, pp. 69-73.

[28] K. Kitamura, K. Kangawa, M. Kawamoto, Y. Ichiki, S. Nakamura, H. Matsuo and T. Eto, "Adrenomedullin: A Novel Hypotensive Peptide Isolated from Human Pheochromocytoma," Biochemical and Biophysical Research Communications, Vol. 192, No. 2, 1993, pp. 553-560. doi:10.1006/bbrc.1993.1451

[29] Y. Li, C. C. Jiang, X. Wang, Y. Zhang, S. Shibahara and K. Takahashi, "Adrenomedullin is a Novel Adipokine: Adrenomedullin in Adipocytes and Adipose Tissues," Peptides, Vol. 28, No. 5, 2007, pp. 1129-1143. doi:10.1016/j.peptides.2007.03.005

[30] I. Nomura, J. Kato, M. Tokashiki and K. Kitamura, "In- creased Plasma Levels of the Mature and Intermediate Forms of Adrenomedullin in Obesity," Regular Peptides, Vol. 158, No. 1-3, 2009, pp. 127-131. doi:10.1016/j.regpep.2009.08.003

[31] G. Vila, M. Riedl, C. Maier, J. Struck, N. G. Morgenthaler, A. Handisurya, G. Prager, B. Ludvik, M. Clodi and A. Luger, "Plasma MR-proADM Correlates to BMI and Decreases in Relation to Leptin after Gastric Bypass Surgery," Obesity, Vol. 17, No. 6, 2009, pp. 1184-1188.

[32] A. Kubo, H. Kurioka, N. Minamino, H. Sato, T. Nishino, M. Iwano, H. Shiiki, H. Matsuo and K. Dohi, "Plasma and Urinary Adrenomedullin in Chronic Glomerulonephritis Patients with Proteinuria," Nephron, Vol. 80, No. 2, 1998, pp. 227-230. doi:10.1007/s004670000440

[33] A. Balat, M. Cekmen, M. Yürekli, H. Gülcan, O. Kutlu, Y. Türköz and S. Yologlu, "Adrenomedullin and Nitrite Levels in Children with Minimal Change Nephrotic Syndrome," Pediatric Nephrology, Vol. 15, No. 1-2, 2000, pp. 70-73. doi: $10.1159 / 000045172$ 